\title{
MENINGKATKAN KEMAMPUAN KANJI MAHASISWA MELALUI MEDIA KARTU HURUF KANJI
}

\author{
Dyah Prasetiani dan Lispridona Diner \\ Universitas Negeri Semarang
}

Email : prasetiani.dyah@gmail.com; $\underline{\text { lisjoost@yahoo.com }}$

\begin{abstract}
Japanese character Kanji is difficult for the students who learn Japanese as a foreign language. Bacause Kanji has stroke order, and also Chinese and Japanese ways of reading. Moreover one character of kanji is presenting one meaning, thus the amount of kanji is massive. The informal interview conduct in some students on Semarang State University, Japanese Department, $2^{\text {nd }}$ semester, reveal that students got problems in memorizing the meaning and also the ways of reading and writing kanji. They often find difficulties while combining two kanji characters become a word (jukugo). Some words they didn't familiar with will cause any further problems such as they didn't know how to apply it into the sentence. Actually, the text book they use has reading and writing practice sections which is enough and proper to learn by themselves. But sometimes students need to make they own sentences in order to make their memory of kanji more lasting. Since the students admitted that they lacks of practice making sentences, therefore, we conducted an experiment in a class, using kanji card in order to overcome the student's problems mentioned above. The result shows that this technique is effective and encourages students to: produce jukugo, produce sentences which using the kanji, students feel fun in learning kanji. But, not quite suitable if we conduct it in a large class.
\end{abstract}

Keywords : kanji, kanji card

\section{PENDAHULUAN}

Dari tahun ke tahun jumlah pembelajar bahasa Jepang di Indonesia semakin meningkat. Data Japan Foundation tahun 2009 menunjukkan bahwa pembelajar Indonesia yang mempelajari bahasa Jepang menduduki peringkat ketiga terbanyak di dunia. Bagi pembelajar Indonesia, yang bahasa ibunya tidak bersistem simbol, bahasa Jepang merupakan bahasa yang sulit dipelajari karena memiliki empat jenis huruf yaitu hiragana, katakana, kanji, dan romaji. Huruf hiragana dan katakana sering disebut sebagai huruf kana. Hiragana digunakan untuk menulis kata-kata yang berasal dari Jepang asli, sedangkan katakana digunakan untuk menulis kosakata yang berasal dari negara selain Jepang. Kanji adalah huruf

yang melambangkan makna dan mempunyai dua cara baca yaitu kunyomi dan onyomi. Romaji adalah huruf alphabet yang kita ketahui. Contoh masing-masing huruf di atas adalah sebagai berikut: kata gohan, jika ditulis dengan huruf hiragana menjadi ごは ん, jika ditulis dengan huruf katakana menjadi ゴハン, jika ditulis dengan huruf kanji menjadi 御飯, jika ditulis dengan huruf romaji menjadi gohan. 
Kesulitan seperti ini pun dialami mahasiswa Universitas Negeri Semarang. Dari hasil observasi dan wawancara informal dengan mahasiswa semester II Prodi Pendidikan Bahasa Jepang Universitas Negeri Semarang, diketahui bahwa mahasiswa mengalami kesulitan dalam cara penulisan, menghafal makna, dan membaca huruf kanji. Penyebab dari kesulitan di atas adalah karakteristik kanji yang unik yaitu memiliki bushu (radikal), kakusuu (jumlah coretan), hitsujun (urutan menulis), serta yomikata (cara baca). Setiap karakteristik kanji memiliki jumlah lebih dari satu, sehingga sulit untuk dihapal. Selain itu, materi yang harus dipelajari terlalu banyak. Dalam satu pertemuan mahasiswa harus menghapal sekitar 10 huruf kanji dasar dan 40 kanji gabungan atau kosakata yang ditulis dengan huruf kanji (jukugo).

Pembelajaran kanji yang dilakukan selama ini menggunakan media flashcard. Namun media tersebut lebih menekankan pada latihan membaca kanji. Mahasiswa kurang mendapatkan latihan menulis kanji di kelas, kurang terampil menggabungkan dua huruf kanji atau lebih menjadi sebuah kosakata (jukugo) dan kurang terlatih menggunakan kosakata tersebut dalam kalimat.

Berdasarkan fakta tersebut di atas, penulis mencoba melakukan penelitian dengan menggunakan kartu kanji sebagai media dalam pembelajaran kanji. Diharapkan teknik ini dapat melibatkan mahasiswa secara aktif belajar dalam kelompok, meningkatkan semangat belajar melalui kerja kelompok karena dapat belajar dari teman sebaya, meningkatkan kemampuan menguasai kanji dan menerapkannya dalam kalimat sehingga kesulitan belajar kanji yang dihadapi mahasiswa di dalam kelas dapat teratasi.

Hasil dari penelitian ini penulis share melalui tulisan ini dengan harapan dapat menambah wawasan dan menjadi alternative pembelajaran kanji.

\section{LANDASAN TEORI}

Penelitian ini memanfaatkan teori yang meliputi konsep-konsep tentang (1) Pengertian media, (2) Media Pembelajaran Kartu Huruf Kanji, (3) Pembelajaran Kanji, (4) Pembelajaran Kanji dengan Media Kartu Kanji

\subsection{Pengertian Media}

Dalam bahasa Arab, media adalah perantara atau pengantar pesan dari pengirim kepada penerima pesan.

Menurut Arsyad (2007:3), media berasal dari bahasa Latin medius yang secara harfiah berarti 'tengah', 'perantara' atau 'pengantar'.

Gerlach dan Ely (dalam Arsyad, 2007:3) mengatakan bahwa media apabila dipahami secara garis besar adalah manusia, materi, atau kejadian yang membangun kondisi yang membuat siswa mampu memperoleh pengetahuan, keterampilan, atau sikap.

Menurut Briggs (dalam Susilana dan Riyana, 2009:205) media pembelajaran adalah sarana fisik untuk menyampaikan isi/materi pembelajaran seperti buku, film, video dan sebagainya.

Menurut Aqib (2013:50), media pembelajaran adalah segala sesuatu yang dapat digunakan untuk menyalurkan pesan dan merangsang terjadinya proses belajar pada si pembelajar (siswa). Makna media pembelajaran lebih luas dari: alat peraga, alat bantu mengajar, dan media audio visual.

Sedangkan menurut Smaldino (2005: 09), media yang menyajikan pesan-pesan terkait dengan tujuan pembelajaran disebut dengan media pembelajaran. Media dapat menjadi komponen sumber belajar atau wahana fisik yang mengandung materi instruksional yang dapat merangsang siswa untuk belajar. Pengertian ini mengandung makna bahwa media merupakan komponen sumber belajar atau wahana fisik yang mengandung materi instruksional di lingkungan siswa yang dapat menarik perhatian siswa untuk belajar. 
Dapat disimpulkan bahwa media pembelajaran adalah segala sesuatu yang dapat menyalurkan pesan, dapat merangsang fikiran, perasaan, dan kemauan peserta didik sehingga dapat mendorong terciptanya proses belajar pada diri peserta didik.

Leshin, Pollock, \& Reigeluth dalam Azhar Arsyad (2007: 36) mengklasifikasi media ke dalam lima kelompok, yaitu (1) media berbasis manusia (guru, instruktor, tutor, main-peran, kegiatan kelompok, fieldtrip), (2) media berbasis cetak (buku, buku penuntun, buku latihan, alat bantu kerja, lembaran lepas), (3) media berbasis visual (buku, alat bantu kerja, bagan, grafik, peta, tranparansi, slide), (4) media berbasis audiovisual (video, film, program slide-tape, televisi), (5) media berbasis komputer (pengajaran dengan bantuan komputer, interaktif video, hypertext).

\subsection{Media Pembelajaran Kartu Huruf Kanji}

Dalam Kamus Besar Bahasa Indonesia (1990:392) definisi dari "Kartu adalah kertas tebal berbentuk persegi panjang (untuk berbagai keperluan, hampir sama dengan karcis)".

Menurut Soeparno (1988:11) media kartu huruf termasuk dalam jenis media pandang nonproyeksi.

Menurut Amin (dalam Arsyad 2010:112) kartu huruf merupakan alat peraga praktis dan menarik bagi kalangan anak-anak khususnya anak berkesulitan membaca yang sangat membutuhkan rangsangan untuk memicu kemampuan belajarnya khususnya kemampuan membaca permulaan.

Dalam pembelajaran kanji, kartu huruf dikembangkan menjadi kartu yang pada salah satu permukaannya bertuliskan sebuah huruf kanji. Kartu ini bisa digunakan sebagai media untuk menghafal, membaca, dan menulis huruf Kanji. Juga dapat digunakan untuk permainan membentuk kosakata (jukugo). Kelebihan dari media kartu huruf adalah praktis, mudah digunakan untuk menghafal dan menyenangkan (mempermudah pelajar untuk belajar).

\subsection{Pembelajaran Kanji}

Di dalam Kokugo Jiten disebutkan 漢字は中国で作られた表意文字。また、 それをまねて日本で作った文字 (1999: 298). Huruf Kanji adalah hyoo'i moji yang awalnya dibuat di Cina. Huruf tersebut kemudian ditiru dan dijadikan huruf Jepang.

Huruf Kanji masuk ke Jepang melalui orang Cina yang bermigrasi ke Jepang sekitar abad ke-4 pada masa berkuasanya dinasti Kan di Cina. Karena itu disebut kanji (huruf dari dinasti kan), 'kan' berarti dinasti Kan, dan ' $j i$ ' berarti huruf. Kanji merupakan huruf hyoo' $i$ moji yaitu sebuah huruf yang menyatakan arti tertentu. Hal ini berarti bahwa semua benda yang ada di dunia dapat ditulis dengan huruf Kanji, terutama kata-kata yang termasuk wago (kata asli Jepang) dan kango (kata serapan dari bahasa Cina). Karena itulah jumlah huruf kanji sangat banyak.

Menurut Sudjianto dan Dahidi (2007: 56-70) huruf kanji memiliki karakteristik:

1) Memiliki bushu, yaitu bagian-bagian radikal pada huruf kanji yang dapat dijadikan dasar untuk pengklasifikasian huruf kanji. Terdapat tujuh macam bushu yaitu hen, tsukuri, kanmuri, ashi, tare, nyoo, dan kamae.

2) Memiliki kakusuu, yaitu jumlah garis atau coretan yang membentuk sebuah kanji. Kanji yang sederhana memiliki sedikit kakusuu, namun kanji yang rumit memiliki banyak kakusuu.

3) Memiliki hitsujun atau urutan penulisan yang harus ditulis dengan benar.

4) Memiliki yomikata atau cara baca. Terdapat dua cara baca yaitu onyomi dan kunyomi. Onyomi merupakan cara baca kanji yang mengikuti pelafalan orang Cina, namun tidak sama persis bunyi aslinya karena disesuaikan dengan pelafalan orang Jepang. Sedangkan untuk makna yang sama dan orang Jepang sudah mempunyai padanan kata dalam bahasa Jepang, dibaca dengan cara baca Jepang asli (kunyomi). 
Hampir semua kanji memiliki dua cara pengucapan $O N$-yomi dan KUN-yomi. Bahkan sebuah huruf kanji bisa memiliki lebih dari satu ON maupun KUN. Biasanya kanji yang berdiri sendiri dibaca dengan $K U N$ sedangkan kanji yang merupakan bagian dari kata gabungan atau jukugo biasanya dibaca dengan $O N$. Sebagai contoh, $\lceil 力 」$ terdiri dari satu huruf sehingga dibaca dengan KUN 'chikara'(tenaga). Sedangkan huruf yang sama pada kata gabungan seperti $\lceil$ 能力」 'nooryoku'(kemampuan) dibaca dengan $O N$ 'ryoku'.

Namun tidak semua jukugo dibaca secara ON-yomi. Ada empat macam cara membaca kanji gabungan (jukugo), yaitu $\mathrm{ON}+\mathrm{ON}, \quad \mathrm{KUN}+\mathrm{KUN}, \quad \mathrm{ON}+\mathrm{KUN}$, KUN+ON. Contoh:

$$
\begin{aligned}
& \text { 心理 'shin ri' (kenyataan ) } \\
& \quad \rightarrow \text { ON+ON } \\
& \text { 真夜中 'ma yo naka' (tengah malam) } \\
& \quad \rightarrow \text { KUN+KUN+KUN } \\
& \text { 音読 'on yomi' (cara baca Cina) } \\
& \quad \rightarrow \text { ON+KUN } \\
& \text { 足音 'ashi oto' (langkah kaki) } \\
& \quad \rightarrow \text { KUN+ON }
\end{aligned}
$$

Ada juga beberapa kanji yang memiliki cara baca khusus, yang kadangkadang tidak sesuai dengan ON maupun KUN. Contohnya:「今朝」 yang berarti "pagi ini" harus dibaca 'kesa', bukan 'kyoo asa' atau lainnya sesuai ON dan KUN dari masing-masing kanji.

Keunikan dari huruf kanji seperti disebut di atas seringkali menyulitkan mahasiswa ketika mempelajarinya. Karena itu Katoo dalam Sudjianto dan Dahidi (2007: 58) menyarankan agar pengajaran huruf kanji bagi orang asing disesuaikan dengan alokasi waktu yang tersedia serta tingkat pengajarannya. Biasanya komposisinya sebagai berikut:
Tabel 2.1. Sasaran Pengajaran Huruf Kanji Bagi Orang Asing

\begin{tabular}{|l|c|c|}
\hline \multicolumn{1}{|c|}{ Level Pengajaran } & $\begin{array}{c}\text { Jumlah } \\
\text { Kanji }\end{array}$ & $\begin{array}{c}\text { Alokasi } \\
\text { Waktu }\end{array}$ \\
\hline $\begin{array}{l}\text { Tingkat Dasar } \\
\text { Tingkat Terampil } \\
\text { Tingkat Mahir }\end{array}$ & $\begin{array}{c}400-500 \\
700-800\end{array}$ & $\begin{array}{c}13 \\
\text { minggu } \\
18 \\
\text { minggu } \\
9 \text { minggu }\end{array}$ \\
\hline Jumlah & $\begin{array}{c}400 \\
\text { minggu }\end{array}$ \\
\hline
\end{tabular}

Pengajaran Kanji di Program Studi Pendidikan Bahasa Jepang Universitas Negeri Semarang juga mengikuti komposisi di atas. Kanji diberikan hingga enam semester. Semester I dan II merupakan tingkat dasar, semester III dan IV merupakan tingkat terampil, dan semester $\mathrm{V}$ dan VI merupakan tingkat mahir. Setiap semester mahasiswa mempelajari sekitar 150 kanji dasar yang diambil dari buku Basic Kanji. Jika dijumlahkan dengan contoh kosakata jukugo yang terdapat dalam buku ajar, maka setiap semester mahasiswa mempelajari sekitar 600-700 kosakata jukugo.

Memperhatikan banyaknya jumlah kanji yang harus dihapalkan, sudah sewajarnya bila pembelajar maupun pengajar mengupayakan cara yang terbaik untuk mempelajari kanji. Setiap cara yang dilakukan memiliki keunggulan dan kelemahan masing-masing.

Hingga saat ini pembelajaran kanji yang dilaksanakan masih bercirikan individual. Mahasiswa cenderung menghapal kanji secara perorangan dengan menggunakan media yang beragam seperti daftar kanji, buku, dan flashcard. Media flashcard yang digunakan oleh pengajar di kelas hingga saat ini, sudah mampu menarik minat belajar mahasiswa namun masih terfokus pada meningkatkan kemampuan membaca kosa kata kanji secara cepat saja. Sementara itu latihan penerapan kosa kata kanji dalam kalimat bahasa Jepang kurang dilatihkan di dalam kelas karena keterbatasan waktu. 
Kegiatan latihan seperti ini mungkin akan dirasakan sulit oleh mahasiswa jika dilakukan secara individu. Karena dia tidak bisa mengetahui langsung apakah kalimat yang ditulisnya benar atau salah. Lain halnya bila dilakukan secara berkelompok. Mahasiswa bisa mendapatkan feedback dan belajar dari teman sebayanya. Karena itu perlu dipikirkan sebuah metode pembelajaran yang bercirikan berkelompok.

\subsection{Pembelajaran Kanji dengan Media Kartu Kanji}

Dalam pembelajaran kanji menggunakan media kartu kanji, mahasiswa membuat beberapa kelompok kecil untuk bekerja dan belajar bersama dalam kelompok. Dapat dikatakan teknik ini dimediasi oleh mahasiswa sendiri sehingga sangat memungkinkan untuk membangun semangat kerja kelompok. Kegiatan belajar yang dilakukan dalam kelompok tidak hanya membahas materi, tetapi juga memecahkan masalah, brainstorming, mengeksplorasi atau menemukan ide-ide baru. Heterogenitas kelompok pun memungkinkan mereka secara tidak langsung belajar tentang budaya dan masalah dinamika kelompok.

Langkah yang dilakukan dapat berupa kegiatan brainstorming atau menjawab pertanyaan. Langkah-langkah ini dapat dimodivikasi sesuai pendapat Knight (2009) "Teachers can utilize a variety of learning structures while providing cooperative learning".

Untuk kebutuhan pembelajaran kanji, maka penulis memodivikasi pembelajaran kanji dengan menyusun media kartu kanji, diskusi, meminta setiap anggota kelompok untuk menuliskan jawaban dengan huruf kanji pada kertas sekaligus mengucapkan cara baca dan menghapalnya agar tidak terjadi keheningan yang dapat membuat mahasiswa bosan.
Secara konkrit langkah yang dilakukan dalam pembelajaran kanji menggunakan media kartu kanji adalah sebagai berikut:

1) Pengajar memberikan penejalasan tentang materi hari ini,

2) Mahasiswa membentuk kelompok kecil,

3) Pengajar memberikan kartu kanji pada tiap kelompok,

4) Pengajar memberikan perintah/pertanyaan pada tiap kelompok,

5) Setiap kelompok mengerjakan perintah/pertanyaan secara bekerjasama

6) Setiap kelompok menuliskan jawaban

7) Presentasi jawaban/diskusi kelas

\section{METODE PENELITIAN}

Penelitian ini merupakan penelitian eksperimen yaitu membandingkan hasil nilai antara kelas eksperimen dan kelas kontrol. Pengumpulan data penelitian dilakukan dengan teknik observasi dan tes.

Populasi yang digunakan dalam penelitian ini adalah mahasiswa Universitas Negeri Semarang. Sedangkan sampel yang digunakan adalah mahasiswa semester 2 angkatan 2013/2014 yang berjumlah 62 orang. Sejumlah 30 mahasiswa pada rombel 1 dijadikan kelas eksperimen, sedangkan 32 mahasiswa pada rombel 2 dijadikan kelas kontrol.

Peneliti mengamati pembelajaran yang dilakukan pada kelas kontrol dan kelas eksperimen, serta melakukan tes pada kelas eksperimen dan kontrol setelah pelaksanaan eksperimen selesai.

\section{HASIL DAN PEMBAHASAN}

Berdasarkan hasil tes yang dilakukan pada kelas kontrol dan kelas eksperimen, diperoleh hasil rata-rata sebagai berikut: rata-rata nilai tes pada kelas kontrol 7.6 dan rata-rata nilai tes pada kelas eksperimen 8.3. 
Dari perbandingan rata-rata nilai kelas kontrol dan kelas eksperimen maka dapat dikatakan bahwa pembelajaran kanji dengan menggunakan media kartu kanji efektif untuk meningkatkan kemampuan kanji mahasiswa.

\section{Perbandingan Pembelajaran}

Pembelajaran kanji pada kelas kontrol dan kelas eksperimen pada tahap dопуии sampai dengan kihon renshuu dilakukan dengan cara yang sama yaitu menggunakan media power point untuk mengenalkan 12 kanji dasar yang dipelajari pada bab 19 buku Basic Kanji Vol 1. Tetapi tahap oyourenshuu berbeda.

Berdasarkan hasil catatan observasi, tahap-tahap pembelajaran kanji dengan menggunakan media kartu kanji yang dilakukan dapat dijabarkan sebagai berikut:

Fukushuu: pengajar mengulang materi minggu lalu (bab 18) dengan menggunakan media power point secara klasikal dan individual. Mahasiswa menyebutkan cara baca kanji yang diperlihatkan oleh pengajar.

Donyuи: pengajar mengenalkan/ mengajarkan kanji baru terutama kakijun (urutan penulisan) dengan menggunakan media power point.

Kihonrenshuu: Mahasiswa mengikuti kakijun kanji tersebut dengan cara soragaki (menulis di udara), kemudian menulis di buku latihan. Serta membaca contoh-contoh jukugo (kanji gabungan) yang tertulis di buku.

Donyuu: dengan menggunakan media power point, pengajar memperlihatkan jukugo kepada mahasiswa. Mahasiswa menyebutkan yomikata (cara baca) kanji tersebut secara klasikal

Kihonrenshuu: pengajar memperlihatkan jukugo kepada mahasiswa dan meminta mahasiswa menyebutkan yomikata kanji tersebut secara kelompok dan individual.
Oyourenshuи. pada kelas kontrol dan eksperimen berbeda.

Pada kelas kontrol adalah sebagai berikut: Mahasiswa membaca yomikata kanji yang tertulis pada bagian yomirenshuu (latihan baca) secara bergiliran.

Sedangkan pada kelas eksperimen, tahap оуоитепshии dilakukan dengan menerapkan media kartu kanji, yaitu dengan cara sebagai berikut:

Pra kegiatan:

1. Pengajar menjelaskan kegiatan kelas yang akan dilakukan

2. Pengajar meminta mahasiswa membentuk kelompok kecil beranggotakan 3-4 orang

3. Pengajar membagikan kartu kanji yang berbeda-beda pada tiap kelompok. Kartu tersebut harus disusun menjadi lima kosakata (jukugo)

Kegiatan:

4. Setiap kelompok mulai menyusun kartu kanji secara bersama-sama. Setelah tersusun tiap anggota kelompok harus menyebutkan cara baca kanji dan artinya sambil dihapalkan

5. Setelah itu tiap anggota kelompok secara bergiliran menulis sebuah kalimat sederhana dengan menggunakan kanji-kanji yang sudah dihapalkan. Tiap kelompok membuat 3-5 kalimat

Pasca kegiatan:

6. Tiap kelompok membacakan kalimat yang telah ditulis

7. Pengajar mengoreksi kalimat yang dibuat oleh tiap kelompok

\section{Kelebihan dan kelemahan:}

Kelebihan:

1. Belajar bekerjasama dalam kelompok kecil

2. Mahasiswa yang memiliki kemampuan lemah jadi termotivasi memaksimalkan kemampuannya untuk dapat menghapal kanji. 
3. Mahasiswa yang biasanya tidak aktif di kelas menjadi aktif

4. Tingkat penguasaan kosakata jukugo meningkat. Serta dapat menerapkan kosakata tersebut dalam sebuah kalimat

Kelemahan:

1. Membutuhkan waktu yang lama dalam penerapannya

2. Karena kegiatan ini dilakukan dalam kelas gemuk, dimana terdapat 10 kelompok, maka monitoring kegiatan kelompok sulit dilakukan oleh pengajar

3. Pada pasca kegiatan, kalimat yang dibuat mahasiswa hanya dikoreksi oleh pengajar, akan lebih baik lagi jika dikoreksi oleh kelompok lain, sehingga melibatkan semua mahasiswa.

\section{KESIMPULAN DAN SARAN}

Media kartu kanji yang diterapkan pada pembelajaran kanji efektif untuk meningkatkan kemampuan kanji mahasiswa. Media inipun meningkatkan kemampuan kerjasama kelompok dalam menghapalkan kanji dan menggunakannya dalam kalimat.

Sebaiknya diterapkan pada kelas kelas kecil. Jika diterapkan pada kelas besar, maka diperlukan pengajar lebih dari satu untuk membantu mengawasi kegiatan perkelompok serta mengecek benar atau salahnya.

Jika pembelajaran seperti ini ingin diterapkan maka perlu dimodivikasi lagi langkah-langkahnya sehingga menjadi lebih praktis dan efisien, baik dari segi waktu maupun pengelolaan kelas.

\section{DAFTAR PUSTAKA}

Aqib, Zainal. 2013. Model-model Media, dan Strategi Pembelajaran Kontekstual (Inovatif). Bandung: CV Yrama Widya.

Arsyad, Azhar. 2007. Media Pembelajaran. Jakarta: PT Raja Grafindo Persada.

Chieko, Kano. Et al. 1991. Basic Kanji Book Vol. 1.Tokyo: Bojinsha Co, Ltd.

Foundation Japan. 2008. Nihongo Noryoku Shiken no Jyukenannai. Jepang: The Japan Foundation

Johnson, David W. dan Johnson, Roger T. 1998. Cooperation in the Classroom: Interaction Book. Holubec: Company Edina, MN

Knight, Jim. 2009. Cooperative Learning: Instructional Coaching. Version 1.2-October 16, 2009. Online http://www.instructionalcoach.org 1. Diunduh Sabtu, 4 Agustus 2013, 15.33

Moleong, L. 2007. Metodologi Penelitian Kualitatif. Bandung: Remaja Rosdakarya

Smaldino, Sharon. 2005. Intructional Technology and Media For Learning. Jakarta: Kencana Perdana

Soeparno. 1988. Media Pengajaran. Intan Pariwara.

Susilana, Rudi. Riyana, Cepi. 2009. Media Pembelajaran: Hakikat, Pengembangan, Pemanfaatan, dan Penilaian. Bandung: CV Wacana Prima. 